\title{
Statistical analysis as a management tool of AIC innovative development
}

\author{
L.V. Egorova ${ }^{l^{*}}$, and I.Y. Vaslavskaya ${ }^{2}$ \\ ${ }^{1}$ Moscow State Medical and Dental University named after A. I. Evdokimov, 127473, Delegatskaya \\ str., 20, p. 1, Moscow, Russia \\ ${ }^{2}$ Kazan (Volga region) Federal University, 420008, Kremlyovskaya str., 18, Kazan, Russia
}

\begin{abstract}
In the agro-industrial complex (hereinafter AIC), innovative development is manifested in the introduction of new technologies for processing agricultural products, the use of elite sowing materials, the use of unconventional, yet efficient management practices, high-tech technology and equipment, and in the use of intangible assets in all their forms. However, the introduction of innovations in agro-industrial complex has its own specificity related to the heterogeneity of the vast territory of the country. The Russian Federation is characterized by the heterogeneity of regions in the area of socio-economic, climatic and geographical factors, which imposes its imprint on the development of national agro-industrial complex. In this article we will present the results of a statistical study of Russia's agriculture development level depending on its territorial location in order to further develop recommendations on optimal investing in innovative development of a specific direction.
\end{abstract}

\section{Introduction}

Opportunities for innovation in agro-industrial complex are wide because it includes several interrelated activities that perform certain technological and economic functions and differ in the type and the purpose of products, requirements for staff qualifications, means of production, necessary resources, technologies and other characteristics. In the context of the national project implementation for the agriculture development with strong state support, effective spending of both budget and private investment for innovation has a significant impact [1]. With this background, the role of statistical studies that allow to cluster the agro-industrial complex of the country on certain signs, to analyze and reveal the close connection between its territorial location and financial results of activities, identify opportunities to invest in innovation, predict the results of returns [2].

\section{Materials and methods}

\footnotetext{
*Corresponding author: LVEgorova@yanex.ru
} 
The public data of the State Statistics Service of the Russian Federation for 2005-2018 are used as materials [3]. Methods: Cluster analysis by Nearest Neighbor, Far Neighbor, Centroid, Median method, Group Mean and Ward, Grouping, Analysis, Benchmark.

\section{Results and discussion}

For research of agro-industrial complex development level of the Russian Federation regions, interspecies assessment of the management efficiency level was used. As a key factor determining the state of agro-industrial complex of the region, we have selected shipment of goods of own production, showing the degree of its development in absolute expression. The regions rating construction is made on the basis of a number of relative indicators characterizing the level of agro-industrial sector development of the region and its potential for further agro-industrial segment development in the region [4]. To weigh the influence degree of the investigated factors, they were divided into 5 groups, each of which has a certain weight based on expert assessments of the National Rating Agency. The study groups of factors included: 1) labor resources of the region (weight - 17.3\%); 2) regional infrastructure (weight - 20.0\%); 3) market volume (demand potential) (weight $22.7 \%$ ); 4) production potential of the regional economy (weight $-21.3 \%$ ); 5) financial stability of the regional budget and enterprises of the region (weight - 18.7\%) [5]. In order to bring of all studied indicators in absolute terms to the relative appearance, weighting on the number of employed in segments of agro-industrial complex in the region per $1 \mathrm{cash}$ resident in the region per 1 ruble of gross regional product was applied, depending on the nature of indicator [6]. In order to bring the type indicators of agriculture, food and processing industry to an integrated form, the weighting of the investigated factors on the volume of own-produced shipped products by activities of the regional agro-industrial complex was performed. Thus it was revealed that during the whole period the production and shipment of agricultural products has clearly expressed regional and demographic specificity. In 2005, enterprises of the Central Federal District shipped products of their own production in the amount of 612.0 billion rubles, i.e. $35.8 \%$ of the all-Russian shipment; enterprises of the North-West Federal District -261.0 billion rubles of AIC products (15.3\%), Volga Federal District shipped products for 302.2 billion rubles or $17.7 \%$; Southern Federal District -214.6 billion rubles or $12.6 \%$ of of all-Russian significance. The share of the remaining federal districts is less than $10 \%$ [7]. That is, the trend has become noticeable that the share which the federal district takes in the total volume of agricultural products shipment depends primarily on the population size, its solvency. A large population and a high proportion of the middle class are the key to the successful development of AIC enterprises in the region.

In the next phase of the study, cluster analysis was conducted by various methods on the factors mentioned above. The following were applied: cluster analysis using the method of nearest and far neighbor, centroid, median, group mean, and Ward. The results of the latter method should be emphasized. The essence of Ward's method is to construct a cluster structure with minimal increase in intergroup dispersion [8]. The number of "migrating" regions during the construction phase is $5 \%$. The optimal number of clusters considering the distance between them, taking into account feature migration and simplicity of construction is 5. Moreover, Ward's method shows the greatest distance between clusters. Following the results of the construction, a model of 5 clusters was obtained, where the 1st group of regions was the leaders in the development of agro-industrial complex, and the 2nd group was the subjects of the Russian Federation with an average level of AIC development, as well as regions not having potential in this segment. Cluster 4 includes 
regions that have neither developed agro-industrial complex nor potential in this segment, but show relatively high indicators of budgetary provision (Kaliningrad region is also referred to this group, yet inconsistently), group 5 consists mainly of regions of the Southern and North Caucasus federal districts, which are not characterized by high indicators of the level of AIC development, but have certain prospects in this direction (table 1, abbreviations in in table 1: oblast - obl., Republic - Rep., Krai - kr.). It was not possible to carry out further analysis using this regional structure (Table 1) in view of the clusters presence consisting of too heterogeneous regions, the reason being an inadequate set of features, largely having multicollinear properties of a set, therefore it is necessary to select the most informative ones among the traits. The research was continued with structurizing ratings. Based on the comparison results of ranking different ways of Russian Federation subjects, the most qualitative assessment was shown by the method developed by RAEX-Analytics publishing house, adapted for the system indicators of agro-industrial complex. It provided a system of indicators showing the best results in minimizing deviations from the "benchmark" [9].

Table 1- Cluster structure of regions of the Russian Federation, built by Ward Method by 32 factors

\begin{tabular}{|c|c|c|c|c|c|}
\hline Region & cluster & Region & cluster & Region & cluster \\
\hline Belgorod obl. & 1 & Murmansk obl. & 2 & Irkutsk obl. & 2 \\
\hline Bryansk obl. & 1 & Novgorod obl. & 2 & Kemerovo obl. & 2 \\
\hline Vladimir obl. & 1 & Vologda obl. & 2 & Novosibirsk obl. & 2 \\
\hline Kaluga obl. & 1 & Volgograd obl. & 2 & Omsk obl. & 2 \\
\hline Kursk obl. & 1 & Rep. of Dagestan & 2 & Tomsk obl. & 2 \\
\hline Lipetsk obl. & 1 & Stavropol kr. & 2 & Primorsky kr. & 2 \\
\hline Moscow obl. & 1 & $\begin{array}{l}\text { Rep. } \\
\text { Bashkortostan }\end{array}$ & 2 & Khabarovsk kr. & 2 \\
\hline Smolensk obl. & 1 & Rep. of Mari El & 2 & Amur obl. & 2 \\
\hline Tambov obl. & 1 & Rep. of Mordovia & 2 & Moscow city & 3 \\
\hline Tver obl. & 1 & Udmurtia & 2 & $\mathrm{~S}$ aint Petersburg city & 3 \\
\hline Vologda obl. & 1 & Chuvashia & 2 & Kaliningrad obl. & 4 \\
\hline Leningrad obl. & 1 & Perm kr. & 2 & $\begin{array}{l}\text { Rep. of Sakha } \\
\text { (Yakutia) }\end{array}$ & 4 \\
\hline Pskov obl. & 1 & Kirov obl. & 2 & Kamchatka kr. & 4 \\
\hline Krasnodar kr. & 1 & Orenburg obl. & 2 & Sakhalin obl. & 4 \\
\hline Rostov obl. & 1 & Penza obl. & 2 & Rep. of Adygea & 5 \\
\hline Rep. of Tatarstan & 1 & Samara obl. & 2 & Rep. of Crimea & 5 \\
\hline $\begin{array}{l}\text { Nizhny } \\
\text { obl. }\end{array}$ & 1 & Saratov obl. & 2 & Sevastopol city & 5 \\
\hline Ivanovo obl. & 2 & Ulyanovsk obl. & 2 & Rep. of Ingushetia & 5 \\
\hline Kostroma obl. & 2 & Kurgan obl. & 2 & Kabardino-Balkarian Rep. & 5 \\
\hline Oryol obl. & 2 & Sverdlovsk obl. & 2 & Karachay-Cherkess Rep. & 5 \\
\hline Ryazan obl. & 2 & Tyumen obl. & 2 & $\begin{array}{l}\text { Rep. of North Ossetia } \\
\text { Alania }\end{array}$ & 5 \\
\hline Tula obl. & 2 & Tyumen obl. & 2 & Astrakhan obl. & 5 \\
\hline Yaroslavl obl. & 2 & Chelyabinsk obl. & 2 & Chechen Rep. & 5 \\
\hline Republic of Karelia & 2 & Rep. of Buryatia & 2 & Rep. of Altai & 5 \\
\hline Komi Republic & 2 & Altai Krai & 2 & & \\
\hline Arkhangelsk obl. & 2 & Krasnoyarsk Krai & 2 & & \\
\hline
\end{tabular}

The minimum deviation from the benchmark according to this method of rating construction was 452 points, while the minimum error of scoring was 609 points, and the weight rating - 672 points (tab. 2). 
Table 2- Comparison of regions rating calculation methods by AIC development level according to data of 2018, score

\begin{tabular}{|c|c|c|c|c|c|}
\hline Region & $\begin{array}{c}\text { RAEX } \\
\text { rating }\end{array}$ & $\begin{array}{l}\text { Deviation } \\
\text { from the } \\
\text { benchmark }\end{array}$ & Region & $\begin{array}{c}\text { RAEX } \\
\text { rating }\end{array}$ & $\begin{array}{l}\text { Deviation } \\
\text { from the } \\
\text { benchmark }\end{array}$ \\
\hline 1 & 2 & 3 & 4 & 5 & 6 \\
\hline Kostroma obl. & 52 & 11 & Udmurtia & 19 & 11 \\
\hline Orenburg obl. & 53 & 8 & Tula obl. & 20 & 4 \\
\hline Rep. of Dagestan & 54 & 6 & Oryol obl. & 21 & 16 \\
\hline Ivanovo obl. & 55 & 4 & Sverdlovsk obl. & 22 & 3 \\
\hline Irkutsk obl. & 56 & 10 & Saratov obl. & 23 & 5 \\
\hline Tyumen obl. & 57 & 19 & Ryazan obl. & 24 & 10 \\
\hline Ulyanovsk obl. & 58 & 1 & Altai Krai & 25 & 8 \\
\hline Yaroslavl obl. & 59 & 10 & Chelyabinsk obl. & 26 & 10 \\
\hline Rep. of Crimea & 60 & 12 & Smolensk obl. & 27 & 24 \\
\hline Kurgan obl. & 61 & 0 & Novosibirsk obl. & 28 & 8 \\
\hline Karachay-Cherkess Rep. & 62 & 0 & Volgograd obl. & 29 & 2 \\
\hline Chuvashia & 63 & 8 & Kaluga obl. & 30 & 3 \\
\hline Sevastopol city & 64 & 10 & Pskov obl. & 31 & 0 \\
\hline \multicolumn{6}{|c|}{ Continuation of table 2} \\
\hline 1 & 2 & 3 & 4 & 5 & 6 \\
\hline Rep. of Komi & 65 & 1 & Bryansk obl. & 32 & 6 \\
\hline Arkhangelsk obl. & 66 & 1 & Tver obl. & 33 & 1 \\
\hline Khabarovsk kr. & 67 & 1 & Rep. of Bashkortostan & 34 & 9 \\
\hline Rep. of Karelia & 68 & 1 & Krasnoyarsk kr. & 35 & 0 \\
\hline Arkhangelsk obl. & 69 & 4 & Kemerovo obl. & 36 & 3 \\
\hline Murmansk obl. & 70 & 0 & Omsk obl. & 37 & 9 \\
\hline Rep. of Khakassia & 71 & 0 & Rep. of Mari El & 38 & 4 \\
\hline Rep. of Buryatia & 72 & 6 & Samara obl. & 39 & 17 \\
\hline Astrakhan obl. & 73 & 2 & Sakhalin obl. & 40 & 13 \\
\hline Rep. of Altai & 74 & 3 & Primorsky kr. & 41 & 2 \\
\hline Zabaykalsky kr. & 75 & 1 & Kabardino-Balkarian Rep. & 42 & 16 \\
\hline Rep. of Sakha & 76 & 3 & Tyumen obl. & 43 & 1 \\
\hline Nenets AO & 77 & 4 & Rep. of Adygea & 44 & 12 \\
\hline Khanty-Mansi AO & 78 & 0 & Novgorod obl. & 45 & 2 \\
\hline Rep. of North Ossetia & 79 & 7 & Vologda obl. & 46 & 6 \\
\hline Chechen Rep. & 80 & 1 & Amur obl. & 47 & 3 \\
\hline Rep. of Kalmykia & 81 & 1 & Kirov obl. & 48 & 7 \\
\hline Chukotka AO & 82 & 1 & Perm kr. & 49 & 13 \\
\hline Yamalo-Nenets AO & 83 & 3 & Kamchatka kr. & 50 & 2 \\
\hline Magadan obl. & 84 & 3 & Tomsk obl. & 51 & 3 \\
\hline Rep. of Tuva & 85 & 1 & Subtotal & - & 452 \\
\hline Rep. of Ingushetia & 86 & 1 & Leningrad obl. & 1 & 6 \\
\hline Jewish Autonomous obl. & 87 & 1 & Saint Petersburg city & 2 & 3 \\
\hline Moscow city & 8 & 6 & Moscow obl. & 3 & 2 \\
\hline Nizhny Novgorod obl. & 9 & 3 & Voronezh obl. & 4 & 2 \\
\hline Kaliningrad obl. & 10 & 0 & Krasnodar kr. & 5 & 1 \\
\hline Vladimir obl. & 11 & 4 & Belgorod obl. & 6 & 3 \\
\hline Tambov obl. & 12 & 9 & Lipetsk obl. & 7 & 2 \\
\hline Kursk obl. & 13 & 2 & Stavropol kr. & 16 & 3 \\
\hline Rostov obl. & 14 & 0 & Rep. of Tatarstan & 17 & 9 \\
\hline Rep. of Mordovia & 15 & 8 & Penza obl. & 18 & 11 \\
\hline
\end{tabular}


The single-factor model of labor productivity showed a deviation from the benchmark of 1392 points, thus, labor productivity is not a sufficient factor to analyze the level of regional AIC development. The model based on the RAEX-Analytics system provides the number of regions with a deviation within three ranks from the position of the similar region in the benchmark model for 46 regions, and the model based on the point system only for 32 regions. There is a noticeable coincidence of the trend in the RAEX-analytics model ranks on the basis of qualitative factors and rating of regions on the total shipment of AIC products, built on the basis of quantitative factor; and in the point model, the deviation of regions levels from the benchmark is rather chaotic (Table 2). Comparison of the obtained results with the reference rating of regions shows that the main factor predetermining the high level of regional AIC development is the shipment of own production products per 1 employed in the AIC. Labour productivity is a key factor in the intensive development of the national economy, it reduces the share of wages weight in the unit price, which entails wage growth, increases investor interest in the industry and enhances opportunities for innovation implementation. Among the regions that have a high level of labor productivity in AIC, there are no regions where the main producing segment is agriculture. Thus, the main driver of high level of labor productivity is the development of high value-added production (processing industry). Such products are divided into the production of tobacco products (Leningrad region (14.3 million rubles per 1 employed) the leader of the indicator at the expense of tobacco factory Philip Morris, the shipment of tobacco products which in 2017 amounted to over 35\% of the All-Russian), as well as the city of St. Petersburg (10.1 million rubles per 1 employed) (at the expense of tobacco factories Bat-SPB, Petro, Nevo tobacco) - about $50 \%$ of the all-Russian shipment, the production of beverages - city of St. Petersburg (10.1 million rubles), Nizhny Novgorod region (7.0 million rubles), Moscow region (6.1 million rubles), Kamchatka Krai (3.3 million rubles). Companies from these regions shipped over $50 \%$ of beverages in 2107 . Production of food products amounted to - Moscow city (4.0 million RUB), Kaliningrad region (6.3 million RUB), Vladimir region (5.8 million RUB), Kamchatka Krai (3.3 million RUB). Equally important indicator is stock returns, which is closely related to productivity. The largest stock returns are observed in export-oriented regions, where the most of shipped products are food: Kaliningrad region and St. Petersburg city (3.7 RUB per 1 RUB of fixed assets, hereinafter FA), Primorsky Krai (3.4 RUB per 1 RUB. FA), then goes Vladimir region (3,3 rubles), Republic of Udmurtia, Tver region and Moscow city (3.2 rubles) [3]. The most cost-effective direction of food sales is export through sea transportation reducing logistical costs. We note that the level of stock returns is distributed across regions fairly evenly. The next factor characterizing the agricultural development level of the subject of the Russian Federation is the food self-sufficiency coefficient, showing how own needs of the region for basic food products (grain, meat, milk, potatoes, vegetables, eggs and fruits) are satisfied at the expense of local producers. In the calculation of this indicator, the distance of the region from the main transport hubs has weight, since cheaper logistics give imported products more competitive advantages and vice versa. In terms of food self-sufficiency integral level, the highest rating is the Republic of Mordovia, the subject fully provides itself with all necessary types of food $(157.7 \%)$ excluding fruit (54\%). High level of self-sufficiency is observed in Kabardino-Balkarian Republic $(132.4 \%)$; overproduction of fruits $(236.5 \%)$ is noted in the region, but the region is not able to fully self-support itself in eggs $(98.2 \%)$, potatoes $(87.1 \%)$. Next go the oblasts of: Lipetsk (124.6\%), Volgograd (121.8\%) and Tyumen (without autonomous districts) (120.4\%).

An important role is played by the share of overdue liabilities in the AIC, characterizing the liquidity of enterprises and being an indicator of its economic condition. In most regions 
the indicator does not exceed $10 \%$, in regions that differ by large quantity of shipped AIC products the indicator is 0 (Belgorod, Kaluga, Lipetsk and other regions). The next indicator is the volume of shipped products per 1 ruble of investment (investor return). The highest investment return was shown by regions where the food and processing industry occupies a large share of the AIC shipment, or regions with increased yields, considering that crop production is the most highly profitable activity after the production of tobacco products - Belgorod oblast (19.9 RUB/1 RUB), Moscow oblast (18.4 RUB/1 RUB), Krasnodar Krai (9.9 RUB/1 RUB). An important indicator is the return per 1 ruble of state support for agriculture, the only indicator which in the rating is directly related exclusively to rural economy. First in the ranking are Moscow (the indicator is taken according to the calculation of the city of St. Petersburg) and St. Petersburg city (45.9 rubles per 1 rubles of state support). Such a high level of return on state support is associated with the high level of solvent demand in the region, as well as the high profitability of investment direction (production of eggs, fruits, vegetables), similar situation is also in the Leningrad (27.5 rubles) and Moscow (20.9 rubles) oblasts, which is connected with their solvent main markets ( cities of St. Petersburg and Moscow). Next are the main agricultural regions with high fertility level and high quality cattle - Krasnodar Krai (26.8 rubles), Belgorod (24.5 rubles), Lipetsk (19.9 rubles) oblasts. Last are indicators related to solvent domestic demand. The main indicator that characterizes negatively the domestic consumption is the proportion of the population with an average per capita income below the subsistence wage. Among the regions with the lowest proportion of poor population are all regions with highly productive agricultural complex and high levels of yield - Republic of Tatarstan (7.7\%), Belgorod oblast (7.9\%), Moscow oblast (8.1\%), Lipetsk oblast (9.0\%), Krasnodar Krai (11.6\%). For comparison - Irkutsk oblast (20.0\%), Chechen Republic (20.6\%), Krasnoyarsk Krai (18.7\%) and others. The latest indicator characterizes the rate of inflation on food products. In most of the agricultural regions, the price of products has hardly changed - Krasnodar Krai (100.6\%), Belgorod oblast (100.5\%), Republic of Tatarstan (101.3\%), Lipetsk oblast (101.4) \%). For comparison - Kaliningrad oblast (106.9\%), Republic of Kalmykia (105.1\%), Tyumen oblast (without autonomous districts) - $103.6 \%$. Consequently, the balance of supply and demand in the most agrarian regions is fairly stable and does not require government interventions, subsidies and fiscal support measures to stabilize prices and has wide opportunities for innovation.

\section{Conclusion}

It is revealed that the budget provision of the region and infrastructure features have a slight impact on the regional AIC development level and the introduction of innovations. Since the export of natural resources is critical in Russia, and the specificity of the tax legislation allows the use of a significant part of the proceeds in the interests of regional budget, there is a situation that regions with the highest level of budgetary provision in addition to large urban agglomerations become regions of Siberia, the Urals, in which the AIC development is difficult due demographic and climate characteristics [10]. These regions can become leaders of AIC innovative development, as there are all necessary prerequisites for this.

\section{References}

1. P.I. Ogorodnikov, N.V. Speshilova, Y.A. Kozhukhovskaya, Bulletin of the Orenburg Scientific Center of the Ural Dept. of RAS, 2 (2019)

2. L.N. Usenko, Accounting and statistics, 2 (54) (2019) 
3. Official website of the Federal State Statistics Service of the Russian Federation URL: https://www.gks.ru/statistic

4. Order of the Government of the Russian Federation dated 06.05.2008 № 671-P On approval of the Federal Plan of Statistical Works

5. Resolution of the Government of the Russian Federation dated 21.06.2008 № 450 On the Ministry of Agriculture

6. E.S. Darda, Agriculture as a factor or foo security. Materials of 3rd International Multidisciplinary Scientific Conference on Social Science and Arts. Sofia, Bulgaria.

7. Official website of the Ministry of Agriculture of the Russian Federation URL: http://mcx.ru/

8. E.S. Darda, N.A. Sadovnikova, Biosciences Biotechnology Research Asia Frequency, 11(3), (2014)

9. Official site of Raex-Analytics. URL: https://raex-a.ru/database/annual-report

10. Official tax website of the Federal Tax Service of the Russian Federation. Tax Code of the Russian Federation. URL: https://www.nalog.ru 